\title{
Seasonal Distribution of Airborne Trace Elements and Water-Soluble Ions in São Paulo Megacity, Brazil
}

\author{
Gisele O. Da Rocha, ${ }^{*, a}$ Pérola C. Vasconcellos, ${ }^{b}$ Simone G. Ávila, ${ }^{b}$ Davi Z. Souza, ${ }^{b}$ \\ Eduardo A. O. Reis, ${ }^{b}$ Pedro V. Oliveira ${ }^{b}$ and Odon Sanchez-Ccoyllo ${ }^{c}$ \\ ${ }^{a}$ Instituto de Química, Universidade Federal da Bahia, Campus de Ondina, \\ 40170-115 Salvador-BA, Brazil \\ ${ }^{b}$ Instituto de Química and Instituto de Astronomia, Geofísica e Ciências Atmosféricas, \\ Universidade de São Paulo (USP), Cidade Universitária-Butantã, 05508-900 São Paulo-SP, Brazil
}

\begin{abstract}
Neste trabalho, as distribuições sazonais de $\mathrm{Al}, \mathrm{Ca}, \mathrm{Cu}, \mathrm{Fe}, \mathrm{K}, \mathrm{Mg}, \mathrm{Na}, \mathrm{Pb}, \mathrm{Zn}$ e de íons majoritários $\left(\mathrm{Cl}^{-}, \mathrm{PO}_{4}{ }^{3-}, \mathrm{NO}_{3}{ }^{-}, \mathrm{SO}_{4}{ }^{2-}, \mathrm{HCOO}^{-}, \mathrm{CH}_{3} \mathrm{COO}^{-}\right.$, oxalato, succinato, $\mathrm{Na}^{+}, \mathrm{NH}_{4}^{+}, \mathrm{K}^{+}, \mathrm{Mg}^{2+}$ e $\mathrm{Ca}^{2+}$ ) foram estudadas na fração PM10 (material particulado menor que $10 \mu \mathrm{m}$ ) na cidade de São Paulo (abril de 2003 a maio de 2004). Os níveis atmosféricos mais elevados foram encontrados para os íons inorgânicos $\mathrm{SO}_{4}{ }^{2-}, \mathrm{NO}_{3}^{-}, \mathrm{Cl}^{-}$e $\mathrm{PO}_{4}{ }^{3-}$, e dentre os íons orgânicos, oxalato e formiato. Os níveis atmosféricos para elementos foram: $\mathrm{Fe}>\mathrm{Al}>\mathrm{Ca}>\mathrm{K}>$ at $>\mathrm{Mg}>\mathrm{Zn}>\mathrm{Cu}>\mathrm{Pb}$. As fontes relevantes foram: (i) queima de combustíveis e/ou queima de biomassa $\left(\mathrm{NO}_{3}^{-}, \mathrm{HCOO}^{-}\right.$, $\left.\mathrm{C}_{2} \mathrm{O}_{4}{ }_{4}^{2-}, \mathrm{K}^{+}, \mathrm{Mg}^{2+}, \mathrm{Ca}^{2+}, \mathrm{Fe}, \mathrm{Pb}, \mathrm{Zn}, \mathrm{Al}, \mathrm{Ca}, \mathrm{Ke} \mathrm{Mg}\right)$, (ii) conversão gás-partícula $\left(\mathrm{SO}_{4}{ }^{2-}\right.$ e $\mathrm{NH}_{4}{ }^{+}$) e (iii) spray marinho $\left(\mathrm{Cl}^{-}, \mathrm{Na}^{+}\right.$e $\left.\mathrm{Na}\right)$.
\end{abstract}

This study deals with the seasonal distribution of $\mathrm{Al}, \mathrm{Ca}, \mathrm{Cu}, \mathrm{Fe}, \mathrm{K}, \mathrm{Mg}, \mathrm{Na}, \mathrm{Pb}$ and $\mathrm{Zn}$ and water soluble ions $\left(\mathrm{Cl}^{-}, \mathrm{PO}_{4}^{3-}, \mathrm{NO}_{3}^{-}, \mathrm{SO}_{4}{ }^{2-}, \mathrm{HCOO}^{-}, \mathrm{CH}_{3} \mathrm{COO}^{-}\right.$, oxalate, succinate, $\mathrm{Na}^{+}, \mathrm{NH}_{4}^{+}$, $\mathrm{K}^{+}, \mathrm{Mg}^{2+}$ and $\mathrm{Ca}^{2+}$ ) found in PM10 samples (particulate matter less than $10 \mu \mathrm{m}$ in diameter) São Paulo City, Brazil, (April 2003-May 2004). Higher atmospheric levels were found for $\mathrm{SO}_{4}{ }^{2-}$, $\mathrm{NO}_{3}^{-}, \mathrm{Cl}^{-}$and $\mathrm{PO}_{4}{ }^{3-}$ while the main organic anions were oxalate and formate. Atmospheric levels for elements were: $\mathrm{Fe}>\mathrm{Al}>\mathrm{Ca}>\mathrm{K}>\mathrm{Na}>\mathrm{Mg}>\mathrm{Zn}>\mathrm{Cu}>\mathrm{Pb}$. Some sources were predominant for some species: (i) fuel burning and/or biomass burning $\left(\mathrm{NO}_{3}^{-}, \mathrm{HCOO}^{-}, \mathrm{C}_{2} \mathrm{O}_{4}^{2-}, \mathrm{K}^{+}, \mathrm{Mg}^{2+}, \mathrm{Ca}^{2+}\right.$, $\mathrm{Fe}, \mathrm{Pb}, \mathrm{Zn}, \mathrm{Al}, \mathrm{Ca}, \mathrm{K}$ and $\mathrm{Mg}$ ), (ii) gas-to-particle conversion $\left(\mathrm{SO}_{4}{ }^{2-}\right.$ and $\left.\mathrm{NH}_{4}^{+}\right)$and (iii) sea salt spray $\left(\mathrm{Cl}^{-}, \mathrm{Na}^{+}\right.$and $\left.\mathrm{Na}\right)$.

Keywords: major ion composition, water-soluble ions, trace elements, seasonal distribution of atmospheric contaminants, airborne particulate matter

\section{Introduction}

Atmospheric particulate matter (PM) plays an important role in both human health and climate of Earth. PM modifies the budget between scattering and absorption of solar radiation reaching the Earth's surface. These particles can also act as cloud condensation nuclei ( $\mathrm{CCN})$ and ice crystals regulating water cycle. ${ }^{1-3}$ Airborne particulate matter is broadly accepted as a potent air pollutant in a typical urban location. It is generated from wide range of sources and contains numerous toxic substances. It triggers respiratory related diseases and impacts the human health. ${ }^{4}$ There are several studies that deal with chronic and acute

*e-mail: giseleor@ufba.br adverse health effects and particulate matter ${ }^{4-8}$ even though our understanding of the exact causes and mechanisms of these effects still remains limited.

According to the World Health Organization (WHO), $4-8 \%$ of deaths occurring annually in the world is related to air pollution. ${ }^{9}$ Coarse inhalable particles may be deposited in the upper respiratory tract whereas fine particles travel deeper into the lungs. Literature reports that the finest particles can reach alveolar regions but it is not obvious in which particular PM size range toxic substances are concentrated. ${ }^{4}$ In several countries, policies of these emissions have been and/or are being established with the aim of facing environmental pollution. For instance, the legislation of European Union regulates PM10 level (particulate matter less than $10 \mu \mathrm{m}$ in diameter) on a daily 
basis to be not higher than $50 \mu \mathrm{g} \mathrm{m}^{-3}$ (as well as it should not exceed more than 7 times per year) and an annual limit of $20 \mu \mathrm{g} \mathrm{m}{ }^{-3} .{ }^{10}$

In the São Paulo metropolitan area (Brazil), mobile emissions are considered the main source of air pollution. In addition, meteorological conditions influence the pollutant concentrations mainly when other emission sources contribute to the air quality during the biomass burning season. ${ }^{11}$

The aim of the present work was to study the seasonal distribution of selected trace elements ( $\mathrm{Al}, \mathrm{Ba}, \mathrm{Ca}, \mathrm{Cr}, \mathrm{Cu}$, $\mathrm{Fe}, \mathrm{K}, \mathrm{Mg}, \mathrm{Mn}, \mathrm{Na}, \mathrm{Pb}$ and $\mathrm{Zn}$ ) and water soluble ions $\left(\mathrm{Cl}^{-}, \mathrm{PO}_{4}^{3-}, \mathrm{NO}_{3}^{-}, \mathrm{SO}_{4}{ }^{2-}, \mathrm{HCOO}^{-}, \mathrm{CH}_{3} \mathrm{COO}^{-}\right.$, oxalate, succinate, $\mathrm{Na}^{+}, \mathrm{NH}_{4}^{+}, \mathrm{K}^{+}, \mathrm{Mg}^{2+}$ and $\mathrm{Ca}^{2+}$ ) found in PM10 samples collected at São Paulo City from April 2003 to May 2004. Concentration levels, species ratios, enrichment factors, statistical treatment of data (Pearson correlation and principal component analysis) and dry deposition flux results segregated by season are presented.

\section{Experimental}

\section{Sampling, meteorological conditions and backward air mass trajectories}

São Paulo site (SPA) $\left(23^{\circ} 33^{\prime} \mathrm{S}\right.$ and $\left.46^{\circ} 44^{\prime} \mathrm{W}\right)$ is at approximately $800 \mathrm{~m}$ above sea level. The collection point in SPA site is located in a green area, within approximately $2 \mathrm{~km}$ of a major highway carrying relatively heavy traffic consisting of a mixed contribution of gasohol-, diesel- and ethanol-fueled vehicles. A high volume PM10 sampler (Energética, Brazil) with a size-selective inlet was placed in an open area on the roof of the Department of Atmospheric Sciences building (University of São Paulo), being about $20 \mathrm{~m}$ above ground level. Before collection, filters were heated at $800^{\circ} \mathrm{C}$ for $8 \mathrm{~h}$ in order to remove any organic contaminants. Samples were collected twice a month from April 2003 to May $2004(\mathrm{n}=28)$ for $24 \mathrm{~h}$ by filtration of the ambient air through a quartz fiber filter (20 cm $\times 25 \mathrm{~cm}$; Energética, Brazil). The concentration of the suspended particles was calculated weighting the filters before and after collection. Just after each collection, filters were properly kept into refrigerator below $-4{ }^{\circ} \mathrm{C}$ until analysis.

Meteorological data such as temperature, relative humidity and precipitation of the period of sample collection were recorded by the climatological station from the Department of Atmospheric Sciences. The temperature varied from 12 to $28{ }^{\circ} \mathrm{C}$, relative humidity varied from 75 to $85 \%$. More detailed meteorological information is described elsewhere. ${ }^{11}$
Backward air mass trajectories by using HYSPLIT model (Hybrid Single Particle Langrangian Integrated Trajectory Model) (Air Resources Laboratory, NOAA, USA) were calculated for $96 \mathrm{~h}$ before the beginning of each sampling and at $500 \mathrm{~m}$ altitude. Four typical backward air mass trajectories arriving at São Paulo (Figure 1) site were observed: type 1, oceanic-continental (Southwestern Brazil) for $43 \%$ of trajectories (12 occurrences); type 2, oceanic-only for $25 \%$ of trajectories ( 7 occurrences); type 3 , continental-only for $21 \%$ of trajectories ( 6 occurrences); and type 4, oceanic-continental (South America) for $11 \%$ of trajectories ( 3 occurrences). The type 1 trajectory was the most abundant of all trajectories but it is noted that there is an oceanic contribution for the majority of trajectories (by type 1 , type 2 or type 4 ) which sum up to $79 \%$ of all trajectories. Since all trajectories were calculated $96 \mathrm{~h}$ before starting sample collection, they have originated in different places, bringing different contributions of air masses. For instance, type 1 trajectory which began on the Atlantic Ocean was most carried to the Southern Region of Brazil, and has probably contributed to particulate matter be aged and modified by typical urban and biomass burning releases before arriving at SPA site collection. Indeed, this trajectory has mainly contributed to mixed character (continental-oceanic) of air masses. The same condition was observed in other literature reports. ${ }^{12,13}$ Type 3 trajectory has begun on Brazilian West-Center Region until arriving in São Paulo. This is a region well-known to possess extensive areas of biomass (forest and sugar cane) burning and also bovine pasture. Type 2 trajectory is essentially oceanic and type 4 trajectory is a mix of continental South American (urban, agricultural and bovine pasture activities) and oceanic contributions. Nonetheless, since wind has also travelled extensively by ocean (types 1 , 2 and 4), urban areas (types 1, 3 and 4), biomass burning (types 1 and 3) and agricultural areas (types 1, 3 and 4), there may have probably been contributed differently for emission of some of those species considered in this study.

\section{Sample preparation and analyses}

For extraction of ion species, sample and blank filters (cuts of $47 \mathrm{~mm}$ diameter) were extracted using a shaker for 90 min with $20 \mathrm{~mL}$ deionized water $\left(18 \mathrm{M} \Omega \mathrm{cm}^{-1}\right)$. After passing through microporous membranes (Millipore Millex ${ }^{\circledR}$ GV, PVDF $0.22 \mu \mathrm{m}$ pore size; $33 \mathrm{~mm}$ diameter), the ionic concentrations of the aqueous extracts were determined by ion chromatography (Metrohm AG, Herisau, Switzerland) with chemical suppression $\left(50 \mathrm{mmol} \mathrm{L} \mathrm{L}^{-1} \mathrm{H}_{2} \mathrm{SO}_{4}\right.$ ) and a conductivity detector. For anion detection $\left(\mathrm{SO}_{4}{ }^{2-}, \mathrm{Cl}^{-}\right.$, $\mathrm{NO}_{2}{ }^{-} \mathrm{NO}_{3}^{-}, \mathrm{F}^{-}, \mathrm{PO}_{4}{ }^{3-}$ and $\mathrm{C}_{2} \mathrm{O}_{4}{ }^{2-}$ ), samples were injected 


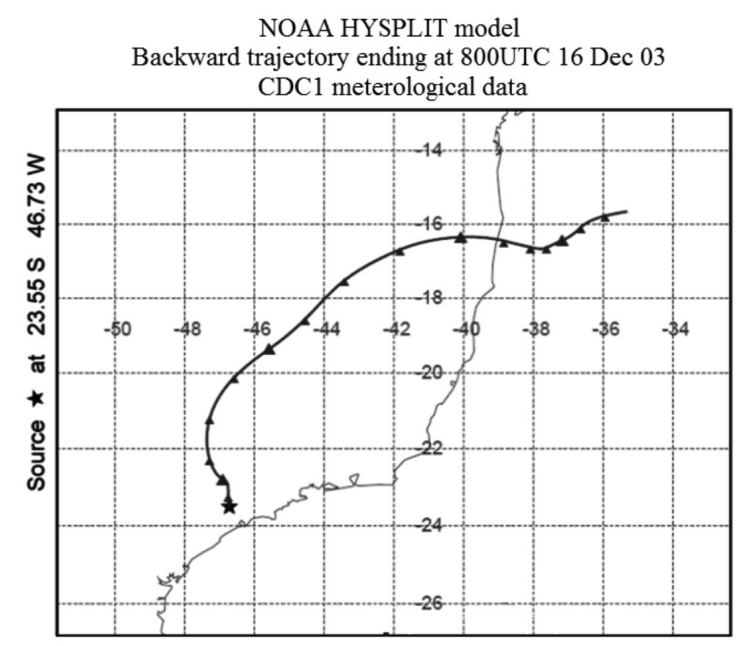

Type 1

NOAA HYSPLIT model

Backward trajectory ending at 800UTC 17 Jun 03 $\mathrm{CDC} 1$ meterological data

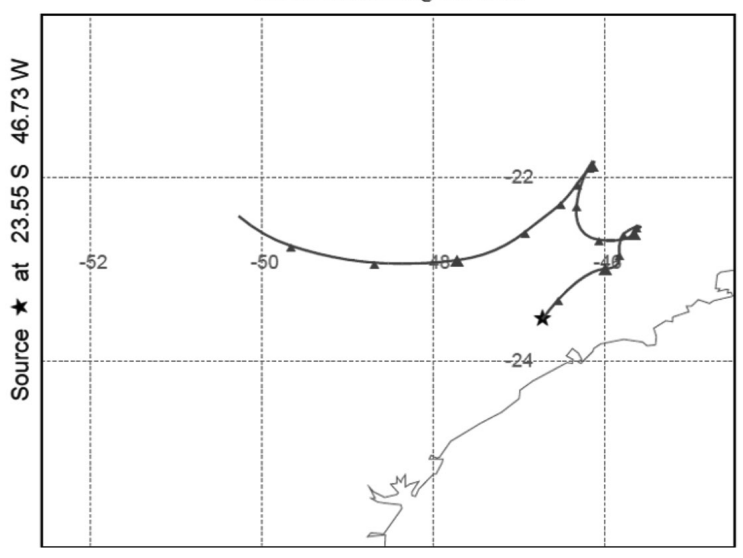

Type 3

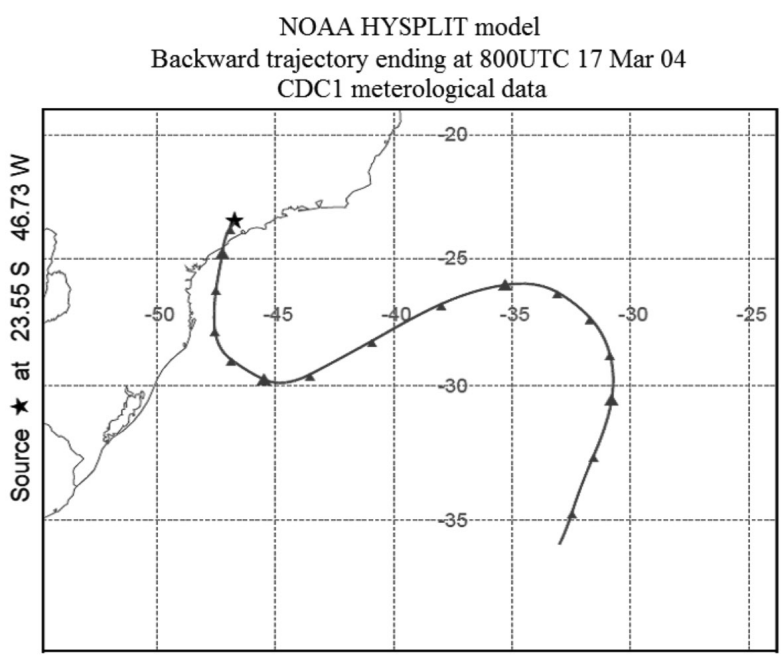

Type 2

NOAA HYSPLIT model Backward trajectory ending at 800UTC 27 Aug 03 $\mathrm{CDC} 1$ meterological data

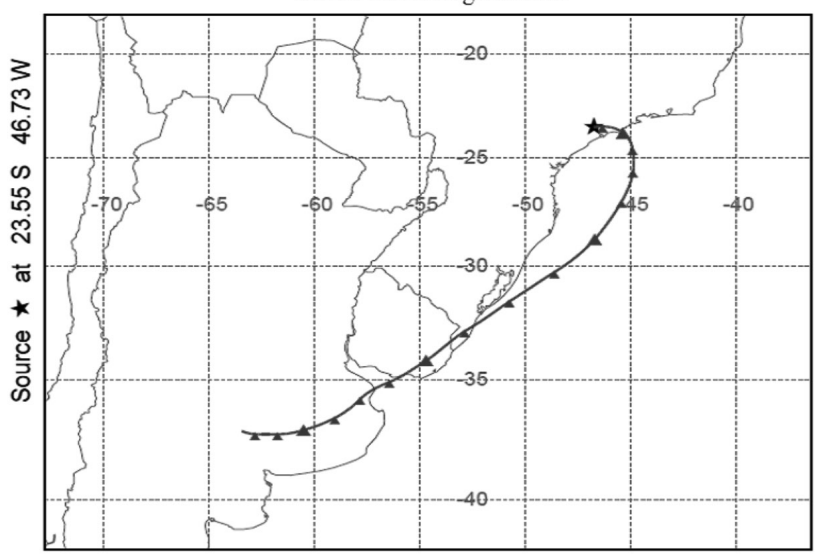

Type 4

Figure 1. Typical backward air mass trajectories ( $96 \mathrm{~h}$ and $500 \mathrm{~m}$ altitude) showing four typical kinds of trajectories arriving at SPA site: type 1: oceaniccontinental (Southwestern Brazil) for $42.9 \%$ of trajectories (12 occurrences); type 2: oceanic-only for $25.0 \%$ of trajectories (7 occurrences); type 3 : continental-only for $21.4 \%$ of trajectories ( 6 occurrences); and type 4: oceanic-continental (South America) for $10.7 \%$ of trajectories ( 3 occurrences).

via a $20 \mu \mathrm{L}$ loop through a Metrosep A Supp 5 250/4.0 mm analytical column. A mixture of $1.0 \mathrm{mmol} \mathrm{L}^{-1} \mathrm{NaHCO}_{3}$ and $3.2 \mathrm{mmol} \mathrm{L}^{-1} \mathrm{Na}_{2} \mathrm{CO}_{3}$ was used as eluent. The suppressor system was regenerated by solution of $50 \mathrm{mmol} \mathrm{L}^{-1} \mathrm{H}_{2} \mathrm{SO}_{4}$ solution pumped through suppressor unit simultaneously with deionized water. The determination of the organic acids was performed injecting the samples via a $20 \mu \mathrm{L}$ loop using a Metrosep Organic Acids 250/7.8 mm analytical column. The system was run in the isocratic mode with solution of perchloric acid $\left(0.5 \mathrm{mmol} \mathrm{L}^{-1}\right)$ as eluent and the chemical suppressor system was regenerated by a solution of $10.0 \mathrm{mmol} \mathrm{L}^{-1} \mathrm{LiCl}$ pumped through the suppressor unit simultaneously with deionized water. A Metrosep C2-150 $150 / 4.0 \mathrm{~mm}$ analytical column was used for cation detection $\left(\mathrm{K}^{+}, \mathrm{NH}_{4}{ }^{+}, \mathrm{Ca}^{2+}, \mathrm{Mg}^{2+}\right.$ and $\left.\mathrm{Na}^{+}\right)$and the eluent used was a solution $2.7 \mathrm{mmol} \mathrm{L}^{-1}$ oxalic acid. The system was run in the isocratic mode.

Recoveries ranged from 109 to $118 \%$ for inorganic anions, from 87 to $107 \%$ for carboxylic anions and from 80 to $101 \%$ for cations. Limit of detection (LOD; $s / n=4$, signal-to-noise ratio) ranged between 3-45 (inorganic anions), 13-35 (organic anions) and 4-24 $\mathrm{ng} \mathrm{m}^{-3}$ (cations). Blank values were subtracted from sample determinations. Fluoride and nitrite levels were found below LOD.

For metal and metalloid determinations, sample and blank filters were digested by using a closed-vessel microwave system (Multiwave 3000, Anton Paar, Austria), equipped with 16 fluoropolymer vessels and ceramic vessel jackets. They support maximum temperature and pressure of $240^{\circ} \mathrm{C}$ and $4 \mathrm{MPa}$, respectively. The internal temperature and 
pressure are monitored only in one controlling vessel using a sensor-protecting glass tube that enters directly in contact with digested solution. A circle filter piece ( $47 \mathrm{~mm}$ diameter) was transferred to the vessel and digested using oxidant mixture $\left(3 \mathrm{~mL} \mathrm{HNO}_{3}+2 \mathrm{~mL} \mathrm{H}_{2} \mathrm{O}_{2}+2 \mathrm{~mL} \mathrm{H} \mathrm{H}_{2} \mathrm{O}\right)$. The heating program was performed in three steps (temperature, ${ }^{\circ} \mathrm{C}$; ramp, min; hold, min): $1(80 ; 5 ; 2), 2(140 ; 5 ; 2)$ and 3 $(190 ; 10 ; 30)$. There is a fourth step for cooling down the system through forced ventilation for $20 \mathrm{~min}$. After digestion, samples and blank solutions were transferred to volumetric polypropylene tubes (Axygen Scientific, California, USA) and made up to $10 \mathrm{~mL}$ with deionized water. The solution was centrifuged for solid particle separation before analysis. A certified reference material of urban particulate matter SRM 1648a (NIST, USA) was also digested following the same procedure described for the samples.

A Spectro Ciros CCD ICP optical emission spectrometer (Spectro Analytical Instruments, Kleve, Germany) equipped with axially-viewed plasma was used. The spectrometer is equipped with a simultaneous CCD (charged-coupled device) solid state detector, polychromator and purged with argon and end-on gas interface for axially viewed configuration to minimize interference. The introduction system was composed of a double pass (Scott-type) spray chamber and a cross-flow nebulizer. The selection of spectral lines was based on spectrometer database. The setup of the ICP instrumental conditions for analysis was: power $1250 \mathrm{~W}$, outer gas flow $12 \mathrm{~L} \mathrm{~min}^{-1}$, intermediate gas flow 1.0 $\mathrm{L} \mathrm{min}^{-1}$, nebulizer gas flow $0.9 \mathrm{~L} \mathrm{~min}^{-1}$ and sample uptake rate $1.5 \mathrm{~L} \mathrm{~min}^{-1}$. The following atomic (I) or ionic (II) wavelengths were used for the elements determination: Al(I) 396.152 nm, Ba(II) 249.773 nm, Ca(II) 396.847 nm, Cr(II) $205.552 \mathrm{~nm}, \mathrm{Cu}$ (I) $327.396 \mathrm{~nm}, \mathrm{Fe}$ (II) $259.940 \mathrm{~nm}$, $\mathrm{K}$ (I) $769.896 \mathrm{~nm}, \operatorname{Mg}$ (I) $285.213 \mathrm{~nm}, \mathrm{Mn}$ (II) $257.610 \mathrm{~nm}$, $\mathrm{Na}$ (I) $588.995 \mathrm{~nm}, \mathrm{~Pb}$ (II) $283.305 \mathrm{~nm}$ and $\mathrm{Zn}$ (I) $213.856 \mathrm{~nm}$.

One standard reference material (SRM) of urban particulate matter SRM 1648a (NIST, USA) was used to check the entire accuracy of the analytical method. The comparisons between experimental and certified values for all elements are in good agreement, considering student's $t$ test at significance level of $95 \%$.

Limits of detection (LOD) were calculated using the background equivalent concentration (BEC) and signal-to-background ratio (SBR):

$$
\begin{aligned}
& \mathrm{BEC}=C_{r s} / \mathrm{SBR} \\
& \mathrm{SBR}=I_{r s}-I_{\text {blank }} / I_{\text {blank }} \\
& \mathrm{LOD}=3 \mathrm{BEC} \mathrm{RSD} / 100
\end{aligned}
$$

where, $C_{r s}$ is the concentration of multi-elemental reference solution $\left(10 \mathrm{mg} \mathrm{L}^{-1}\right), I_{r s}$ and $I_{\text {blank }}$ are the emission intensities for the multi-elemental reference $\left(10 \mathrm{mg} \mathrm{L}^{-1}\right)$ and blank solutions, and RSD is the relative standard deviation for ten consecutive measurements of blank solution. The estimated values for the limits of detection were: $\mathrm{Al}=1.58 \mu \mathrm{g} \mathrm{g}^{-1}$, $\mathrm{Ba}=0.024 \mu \mathrm{g} \mathrm{g}^{-1}, \mathrm{Ca}=0.027 \mu \mathrm{g} \mathrm{g}^{-1}, \mathrm{Cr}=0.075 \mu \mathrm{g} \mathrm{g}^{-1}$, $\mathrm{Cu}=0.015 \mu \mathrm{g} \mathrm{g}^{-1}, \mathrm{Fe}=0.066 \mu \mathrm{g} \mathrm{g}^{-1}, \mathrm{~K}=0.0085 \mu \mathrm{g} \mathrm{g}^{-1}$, $\mathrm{Mg}=0.045 \mu \mathrm{g} \mathrm{g}^{-1}, \mathrm{Mn}=0.009 \mu \mathrm{g} \mathrm{g}^{-1}, \mathrm{Na}=0.426 \mu \mathrm{g} \mathrm{g}^{-1}$, $\mathrm{Pb}=0.084 \mu \mathrm{g} \mathrm{g}^{-1}$ and $\mathrm{Zn}=0.027 \mu \mathrm{g} \mathrm{g}^{-1}$.

\section{Statistical tests}

Experimental data were analyzed by calculating the Spearman correlation coefficients using STATISTICA 6.0 (Statsoft, USA) program. Also principal component analysis (PCA) using Ward method and Euclidian distances were performed. Calculations were performed using the individual experimental values for each sample.

\section{Results and Discussion}

\section{Trace elements and ion composition of PM10 samples}

The seasonal distributed major ions and elements in PM10 samples are presented in Table 1. PM10 average concentrations ranged from 33 to $58 \mu \mathrm{g} \mathrm{m}^{-3}$ for Summer 2003-2004 and Autumn 2003, respectively. According to Brazilian law and recommendation from $\mathrm{WHO},{ }^{9}$ the recommended PM10 concentration is $50 \mu \mathrm{g} \mathrm{m}^{-3}$. However, PM10 levels as high as $116 \mu \mathrm{g} \mathrm{m}^{-3}$ in some Autumn and Winter days of 2003 were observed. Table 2 shows relative contributions (\%) of major ions and elements to PM10 concentrations by season, as considered in this study. Moreover, minor organic constituents ( $n$-alkanes, pristane, phytane and $\mathrm{PAH})^{14}$ from the same set of samples are also stated in the same table. Ion and element percentages presented 18.6, 21.4, 16.9, 21.6 and 14.5\% of PM10 levels found in Autumn 2003, Winter 2003, Spring 2003, Summer 2003-2004 and Autumn 2004, respectively. Even though ion and element percentage contributions to PM10 were considered by season, those levels are close to found in urban regions. Unknown percentages are certainly due to EC/OC (elemental carbon/organic carbon) levels, not measured in this study.

Higher atmospheric levels were found for $\mathrm{SO}_{4}{ }^{2-}$, $\mathrm{NO}_{3}^{-}, \mathrm{Cl}^{-}$and $\mathrm{PO}_{4}{ }^{3-}$ while the main organic anions were oxalate and formate. For cations, higher levels were found for $\mathrm{NH}_{4}^{+}, \mathrm{Ca}^{2+}$ and $\mathrm{Na}^{+}$. Atmospheric levels for elements were $\mathrm{Fe}>\mathrm{Al}>\mathrm{Ca}>\mathrm{K}>\mathrm{Na}>\mathrm{Mg}>\mathrm{Zn}>\mathrm{Cu}>\mathrm{Pb}$. Cations, $\mathrm{HCOO}^{-}, \mathrm{NO}_{3}^{-}, \mathrm{PO}_{4}{ }^{3-}, \mathrm{Fe}, \mathrm{Al}, \mathrm{Ca}, \mathrm{K}, \mathrm{Mg}, \mathrm{Pb}$ and $\mathrm{Zn}$ presented higher atmospheric levels during Autumn 2003 and Winter 2003. A clear seasonal tendency is 
Table 1. Concentration levels $\left(\mathrm{ng} \mathrm{m}^{-3}\right)$ for elementos and ions in PM10 samples

\begin{tabular}{|c|c|c|c|c|c|c|c|c|c|c|}
\hline \multirow{2}{*}{ Species } & \multicolumn{2}{|c|}{ Autumn 2003} & \multicolumn{2}{|c|}{ Winter 2003} & \multicolumn{2}{|c|}{ Spring 2003} & \multicolumn{2}{|c|}{ Summer 2003-2004 } & \multicolumn{2}{|c|}{ Autumn 2004} \\
\hline & Mean \pm sd & (Min - Max) & Mean \pm sd & (Min - Max) & Mean \pm sd & (Min - Max) & Mean \pm sd & (Min - Max) & Mean \pm sd & (Min - Max) \\
\hline $\mathrm{Cl}^{-}$ & $296 \pm 264$ & $(87-766)$ & $374 \pm 206$ & $(148-593)$ & $221 \pm 230$ & $(10-682)$ & $353 \pm 280$ & $(72-703)$ & $314 \pm 146$ & $(115-499)$ \\
\hline $\mathrm{NO}_{3}^{-}$ & $1538 \pm 1210$ & $(429-3625)$ & $1404 \pm 721$ & $(435-2036)$ & $784 \pm 721$ & $(115$ - 2099) & $411 \pm 210$ & $(292-785)$ & $628 \pm 638$ & $(131-1703)$ \\
\hline $\mathrm{PO}_{4}{ }^{3-}$ & $66 \pm 60$ & $(7-157)$ & $10 \pm 7$ & $(5-18)$ & $19 \pm 16$ & $(1-38)$ & $12 \pm 8$ & $(2-20)$ & $11 \pm 6$ & $(4-16)$ \\
\hline $\mathrm{SO}_{4}{ }^{2-}$ & $1805 \pm 1244$ & $(592-3381)$ & $2317 \pm 1404$ & $(1083-4113)$ & $2146 \pm 1410$ & $(687-4369)$ & $2205 \pm 1406$ & $(893-4585)$ & $1771 \pm 1176$ & $(600-3689)$ \\
\hline $\mathrm{HCOO}^{-}$ & $83 \pm 50$ & $(2-144)$ & $168 \pm 66$ & $(125-244)$ & $46 \pm 51$ & $(12-142)$ & $30 \pm 22$ & $(12-62)$ & $25 \pm 6$ & $(17-31)$ \\
\hline $\mathrm{C}_{2} \mathrm{O}_{4}{ }^{2-}$ & $162 \pm 84$ & (59 296) & $181 \pm 86$ & $(69-260)$ & $196 \pm 150$ & $(26-464)$ & $137 \pm 55$ & $(56-210)$ & $75 \pm 35$ & $(47-134)$ \\
\hline succinate & $41 \pm 17$ & $(5-64)$ & $19 \pm 12$ & $(8-31)$ & $26 \pm 3$ & $(22-29)$ & $47 \pm 60$ & $(4-151)$ & $32 \pm 10$ & $(20-43)$ \\
\hline $\mathrm{CH}_{3} \mathrm{COO}^{-}$ & $11 \pm 5$ & $(2-18)$ & $12.7 \pm 8.5$ & $(2-22)$ & $12 \pm 11$ & $(2-30)$ & $6 \pm 10$ & $(2-24)$ & $10 \pm 6$ & $(2-17)$ \\
\hline $\mathrm{Na}^{+}$ & $328 \pm 224$ & $(96-531)$ & $307 \pm 267$ & $(67-682)$ & $148 \pm 106$ & $(27-29)$ & $329 \pm 286$ & $(42-637)$ & $201 \pm 199$ & $(26-416)$ \\
\hline $\mathrm{NH}_{4}^{+}$ & $687 \pm 409$ & $(270-1263)$ & $1279 \pm 899$ & $(493-2316)$ & $955 \pm 730$ & $(79-1763)$ & $801 \pm 686$ & $(212-1988)$ & $445 \pm 324$ & $(146-852)$ \\
\hline $\mathrm{K}^{+}$ & $372 \pm 181$ & $(160-571)$ & $722 \pm 557$ & $(144-1342)$ & $196 \pm 32$ & $(152-249)$ & $196 \pm 59$ & $(106-271)$ & $122 \pm 65$ & $(36-194)$ \\
\hline $\mathrm{Mg}^{2+}$ & $79 \pm 45$ & $(36-159)$ & $46 \pm 21$ & $(17-62)$ & $53 \pm 40$ & $(17-132)$ & $34 \pm 41$ & $(7-98)$ & $20 \pm 14$ & $(7-39)$ \\
\hline $\mathrm{Ca}^{2+}$ & $675 \pm 444$ & $(289-1269)$ & $542 \pm 259$ & $(195-820)$ & $387 \pm 165$ & $(219-686)$ & $310 \pm 93$ & $(175-438)$ & $192 \pm 95$ & $(36-256)$ \\
\hline $\mathrm{Cu}$ & $32 \pm 19$ & (7- 59) & $26 \pm 9$ & $(14-36)$ & $26 \pm 26$ & $(6-80)$ & $38 \pm 27$ & $(14-81)$ & $31 \pm 19$ & $(13-59)$ \\
\hline $\mathrm{Fe}$ & $1141 \pm 765$ & $(453-2176)$ & $893 \pm 612$ & $(169-1657)$ & $361 \pm 219$ & $(111-713)$ & $334 \pm 145$ & $(95-491)$ & $405 \pm 174$ & $(141-630)$ \\
\hline $\mathrm{Pb}$ & $42 \pm 33$ & $(15-96)$ & $24 \pm 5$ & $(19-29)$ & $19 \pm 13$ & $(7-37)$ & $27 \pm 22$ & $(11-60)$ & $15 \pm 10$ & $(1-27)$ \\
\hline $\mathrm{Zn}$ & $118 \pm 96$ & $(47-266)$ & $86 \pm 68$ & $(16-180)$ & $55 \pm 32$ & $(7-94)$ & $91 \pm 60$ & $(21-153)$ & $67 \pm 21$ & $(35-92)$ \\
\hline $\mathrm{Al}$ & $924 \pm 751$ & $(182-1961)$ & $914 \pm 760$ & $(102-1882)$ & $342 \pm 194$ & $(77-700)$ & $321 \pm 114$ & $(156-457)$ & $252 \pm 145$ & $(120-496)$ \\
\hline $\mathrm{Ca}$ & $1024 \pm 385$ & $(656-1553)$ & $1104 \pm 198$ & $(913-1302)$ & $481 \pm 155$ & $(326-761)$ & $472 \pm 96$ & $(421-641)$ & $321 \pm 14$ & $(306-331)$ \\
\hline K & $559 \pm 394$ & $(261-1268)$ & $716 \pm 474$ & $(186-1116)$ & $253 \pm 30$ & $(215-306)$ & $243 \pm 42$ & $(188-285)$ & $259 \pm 72$ & $(161-360)$ \\
\hline $\mathrm{Mg}$ & $247 \pm 97$ & $(80-365)$ & $245 \pm 150$ & $(40$ - 379) & $121 \pm 45$ & $(85-217)$ & $127 \pm 71$ & $(72-246)$ & $140 \pm 98$ & $(51-250)$ \\
\hline $\mathrm{Na}$ & $529 \pm 185$ & $(291-796)$ & $579 \pm 178$ & $(378-784)$ & $411 \pm 138$ & $(274-677)$ & $604 \pm 339$ & $(321-1076)$ & $465 \pm 159$ & $(297-633)$ \\
\hline $\mathrm{PM} 10 /\left(\mu \mathrm{g} \mathrm{m}^{-3}\right)$ & $58 \pm 38$ & $(27-116)$ & $56 \pm 54$ & $(26-89)$ & $43 \pm 35$ & $(13-117)$ & $33 \pm 4$ & $(26-36)$ & $40 \pm 16$ & $(28-67)$ \\
\hline
\end{tabular}

sd: standard deviation; Min: minimum concentration level; Max: maximum concentration level.

Table 2. Percentage contributions of each class of chemical, in relation to PM10 levels

\begin{tabular}{|c|c|c|c|c|c|c|c|c|c|c|}
\hline \multirow[b]{2}{*}{ Species } & \multicolumn{2}{|c|}{ Autumn 2003} & \multicolumn{2}{|c|}{ Winter 2003} & \multicolumn{2}{|c|}{ Spring 2003} & \multicolumn{2}{|c|}{ Summer 2003-2004 } & \multicolumn{2}{|c|}{ Autumn 2004} \\
\hline & $\begin{array}{l}\text { Mean }^{\mathrm{a}} / \\
\left(\mathrm{ng} \mathrm{m}^{-3}\right)\end{array}$ & $\begin{array}{c}\text { Contribution }{ }^{\mathrm{b}} / \\
\%\end{array}$ & $\begin{array}{l}\text { Mean }^{\mathrm{a}} / \\
\left(\mathrm{ng} \mathrm{m}^{-3}\right)\end{array}$ & $\begin{array}{c}\text { Contribution }^{\mathrm{b}} / \\
\%\end{array}$ & $\begin{array}{l}\text { Mean }^{\mathrm{a}} / \\
\left(\mathrm{ng} \mathrm{m}^{-3}\right)\end{array}$ & $\begin{array}{c}\text { Contribution }{ }^{\mathrm{b}} / \\
\%\end{array}$ & $\begin{array}{l}\operatorname{Mean}^{\mathrm{a}} / \\
\left(\mathrm{ng} \mathrm{m}^{-3}\right)\end{array}$ & $\begin{array}{c}\text { Contribution }^{\mathrm{b}} / \\
\%\end{array}$ & $\begin{array}{l}\text { Mean }^{\mathrm{a}} / \\
\left(\mathrm{ng} \mathrm{m}^{-3}\right)\end{array}$ & $\begin{array}{c}\text { Contribution } / \\
\%\end{array}$ \\
\hline Major ion & 6143 & 10.6 & 7382 & 13.2 & 5189 & 12.1 & 4871 & 14.8 & 3846 & 9.6 \\
\hline Element & 4616 & 8.0 & 4587 & 8.2 & 2069 & 4.8 & 2257 & 6.8 & 1955 & 4.9 \\
\hline Organic $^{c}$ & 44 & 0.08 & 27 & 0.05 & 20 & 0.05 & 15 & 0.05 & 24 & 0.06 \\
\hline Unkown $^{\mathrm{d}}$ & 47197 & 81.4 & 44004 & 78.6 & 35721 & 83.1 & 25857 & 78.4 & 34174 & 85.4 \\
\hline
\end{tabular}

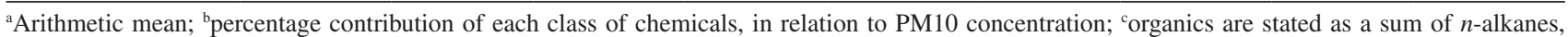
pristine, phytane and PAH mean values found in the same set of samples; ${ }^{14} \mathrm{~d}$ unexplained concentration of PM10 by this study.

observed for those species since they presented higher levels in Autumn 2003 and Winter 2003 than in the other seasons for the most species. In general, climate in São Paulo State is normally characterized by dry Autumns and Winters and rainy Summers and Springs. With higher precipitations, Spring 2003 and Summer 2003-2004 have shown lower levels of these species due to more efficient (wet) removal mechanisms. Conversely, Autumn 2004 showed a different tendency due to higher precipitations rates $(270 \mathrm{~mm})$ decreasing the atmospheric pollutant levels. For oxalate, $\mathrm{CH}_{3} \mathrm{COO}^{-}$and succinate, the levels found in the Spring 2003 were higher than those from Autumn and Winter. Probably biogenic sources (metabolism of vegetation, bacterial and/or fungi) ${ }^{15-17}$ were relevant for them during this season. There were no significant differences among seasons for $\mathrm{SO}_{4}{ }^{2-}$ and $\mathrm{Cl}^{-}$while for the elements $\mathrm{Cu}$ and $\mathrm{Na}$ higher levels were observed during Summer. Species with no clear seasonal trend might possess different (biogenic and/or anthropic) sources contributions or removal efficiencies throughout seasons. Vehicular emissions might be one important source for $\mathrm{SO}_{4}{ }^{2-}$.

Ion balance calculations were done for all seasons (Table 3). The $\Sigma$ cations/ $\Sigma$ anions ratios were higher than ones for all seasons except for Autumn 2004 $(\Sigma$ cations $/ \Sigma$ anions $=0.8)$. The $\Sigma$ cations $/ \Sigma$ anions ratios smaller than 1.0 suggest that negative charges from anions were not fully neutralized by positive charges from cations. This cation deficiency may probably be due to $\mathrm{H}^{+}$ 
ion contribution (not measured in this study) to $\Sigma$ cations. In the other seasons, $\Sigma$ cations/ $\Sigma$ anions ratios were higher than 1.0. In these cases, there is an anion deficiency maybe due to carbonate and bicarbonate ions (not measured in this work).

Ion diagnostic ratios (Table 4) were done in order to investigate how ion species are related to each other. $\mathrm{NH}_{4}{ }^{+} / \mathrm{SO}_{4}{ }^{2-}$ ratio around the unity (1.0) gives the idea about secondary process (gas-to-particle conversion) via reaction between their vapor precursors $\left(\mathrm{NH}_{3}\right.$ and $\left.\mathrm{SO}_{2}\right)$ forming either $\mathrm{NH}_{4} \mathrm{HSO}_{4}$ or $\left(\mathrm{NH}_{4}\right)_{2} \mathrm{SO}_{4}$. These are non-volatile substances, generating then new particles. ${ }^{13}$ Since formation of $\mathrm{NH}_{4} \mathrm{Cl}$ and $\mathrm{NH}_{4} \mathrm{NO}_{3}$ are reversible, they might be found in PM in highly variable levels. During Autumn 2003, Spring 2003 and Summer 2003-2004, it seemed to have enough gaseous $\mathrm{NH}_{3}$ to neutralize $\mathrm{SO}_{2}$ because $\mathrm{NH}_{4}{ }^{+} / \mathrm{SO}_{4}{ }^{2-}$ ratios were, respectively, 1.0, 1.2 and 1.0. When the following $\mathrm{NH}_{4}{ }^{+} /\left(\mathrm{SO}_{4}{ }^{2-}+\mathrm{NO}_{3}{ }^{-}\right), \mathrm{NH}_{4}{ }^{+} /\left(\mathrm{SO}_{4}{ }^{2-}+\mathrm{Cl}^{-}\right)$and $\mathrm{NH}_{4}{ }^{+} /\left(\mathrm{NO}_{3}{ }^{-}+\mathrm{Cl}^{-}\right)$ratios are considered, it is suggested that for Winter $2003 \mathrm{NH}_{4}^{+} /\left(\mathrm{SO}_{4}^{2-}+\mathrm{NO}_{3}^{-}\right)$ratio $=1.0$ and
$\mathrm{NH}_{4}{ }^{+} /\left(\mathrm{SO}_{4}{ }^{2-}+\mathrm{Cl}^{-}\right)$ratio $=1.2$, gaseous $\mathrm{NH}_{3}$ reacted to vapor $\mathrm{SO}_{2}, \mathrm{HCl}$ and/or $\mathrm{HNO}_{3}$. Values below 1.0 for $\mathrm{NH}_{4}{ }^{+} / \mathrm{SO}_{4}{ }^{2-}$, $\mathrm{NH}_{4}^{+} /\left(\mathrm{SO}_{4}^{2-}+\mathrm{NO}_{3}^{-}\right)$and $\mathrm{NH}_{4}^{+} /\left(\mathrm{SO}_{4}{ }^{2-}+\mathrm{Cl}^{-}\right)$ratios for Autumn 2004 show that there was not enough $\mathrm{NH}_{3}$ to neutralize gaseous acids and it was probably done by crustal cations from dust resuspension (as it could be demonstrated by $\mathrm{Na}^{+} / \mathrm{Cl}^{-}$ratio $=1.0$ for Spring 2003 and Autumn 2004).

The ion $\mathrm{HCOO}^{-}$may be formed from precursors emitted by vehicles and vegetation and is used as a tracer of secondary processes while $\mathrm{CH}_{3} \mathrm{COO}^{-}$is mainly emitted by fuel burning, being then a primary source tracer. When $\mathrm{HCOO}^{-} / \mathrm{CH}_{3} \mathrm{COO}^{-}$ratio is higher than 1.0, secondary sources are likely to prevail over primary sources. In all studied periods, $\mathrm{HCOO}^{-} / \mathrm{CH}_{3} \mathrm{COO}^{-}$ratios were higher than 1.0. $\mathrm{HCOO}^{-} / \mathrm{CH}_{3} \mathrm{COO}^{-}$ratio ranged from 3.2 (Autumn 2004) to 17.0 (Winter 2003), indicating that photochemical reactions might be more important for the formation of these ions. ${ }^{12}$

According to Souza et al. $,^{18} \mathrm{SO}_{4}{ }^{2-}, \mathrm{Na}^{+}, \mathrm{K}^{+}, \mathrm{Ca}^{2+}$ and $\mathrm{Mg}^{2+}$ in the atmospheric particulate matter may have sea salt spray origin. In this way, the marine origin portion can

Table 3. Ion balance considering the seasonal ion concentrations of PM10 samples (units in neq $\mathrm{m}^{-3}$ )

\begin{tabular}{|c|c|c|c|c|c|}
\hline Species & Autumn 2003 & Winter 2003 & Spring 2003 & Summer 2003-2004 & Autumn 2004 \\
\hline $\mathrm{Cl}^{-}$ & 8.4 & 10.5 & 6.2 & 9.9 & 8.8 \\
\hline $\mathrm{NO}_{3}^{-}$ & 24.8 & 22.6 & 12.6 & 6.6 & 10.1 \\
\hline $\mathrm{PO}_{4}^{3-}$ & 2.1 & 0.3 & 0.6 & 0.4 & 0.3 \\
\hline $\mathrm{SO}_{4}^{2-}$ & 37.6 & 48.3 & 44.7 & 45.9 & 36.9 \\
\hline $\mathrm{HCOO}^{-}$ & 1.9 & 3.7 & 1.0 & 0.7 & 0.6 \\
\hline $\mathrm{C}_{2} \mathrm{O}_{4}^{2-}$ & 3.7 & 4.1 & 4.5 & 3.11 & 1.7 \\
\hline Succinate & 0.7 & 0.3 & 0.5 & 0.8 & 0.6 \\
\hline $\mathrm{CH}_{3} \mathrm{COO}^{-}$ & 0.2 & 0.2 & 0.2 & 0.1 & 0.2 \\
\hline $\mathrm{Na}^{+}$ & 14.3 & 13.3 & 6.4 & 14.3 & 8.8 \\
\hline $\mathrm{NH}_{4}^{+}$ & 38.2 & 71.0 & 53.1 & 44.5 & 24.7 \\
\hline $\mathrm{K}^{+}$ & 9.6 & 18.5 & 5.0 & 5.0 & 3.1 \\
\hline $\mathrm{Mg}^{2+}$ & 6.5 & 3.8 & 4.4 & 2.9 & 1.7 \\
\hline $\mathrm{Ca}^{2+}$ & 33.8 & 27.1 & 19.3 & 15.5 & 9.6 \\
\hline ¿Cations & 102 & 134 & 88.3 & 82.2 & 47.9 \\
\hline ¿Anions & 79.3 & 90.2 & 70.3 & 67.6 & 59.2 \\
\hline$\Sigma$ Cations/乏Anions & 1.3 & 1.5 & 1.3 & 1.2 & 0.8 \\
\hline Cation deficiency & - & - & - & - & 11.3 \\
\hline Anion deficiency & 23.0 & 43.7 & 17.9 & 14.6 & - \\
\hline
\end{tabular}

Table 4. Ion ratios (based in neq $\mathrm{m}^{-3}$ values) according to seasons in the PM10 samples

\begin{tabular}{|c|c|c|c|c|c|}
\hline Ion ratios & Autumn 2003 & Winter 2003 & Spring 2003 & Summer 2003-2004 & Autumn 2004 \\
\hline $\mathrm{NH}_{4}^{+} / \mathrm{SO}_{4}^{2-}$ & 1.0 & 1.5 & 1.2 & 1.0 & 0.7 \\
\hline $\mathrm{NH}_{4}^{+} /\left(\mathrm{SO}_{4}^{2-}+\mathrm{NO}_{3}^{-}\right)$ & 0.6 & 1.0 & 0.9 & 0.8 & 0.5 \\
\hline $\mathrm{NH}_{4}^{+} /\left(\mathrm{SO}_{4}^{2-}+\mathrm{Cl}^{-}\right)$ & 0.8 & 1.2 & 1.0 & 0.8 & 0.5 \\
\hline $\mathrm{Na}^{+} / \mathrm{Cl}^{-}$ & 1.7 & 1.3 & 1.0 & 1.4 & 1.0 \\
\hline $\mathrm{HCOO}^{-} / \mathrm{CH}_{3} \mathrm{COO}^{-}$ & 10 & 17 & 5.0 & 6.2 & 3.2 \\
\hline
\end{tabular}


be calculated. Sea salt contribution for ions $\mathrm{Cl}^{-}, \mathrm{SO}_{4}{ }^{2-}, \mathrm{K}^{+}$, $\mathrm{Ca}^{2+}$ and $\mathrm{Mg}^{2+}$ from PM10 were calculated based on typical proportions between major ions from sea water ${ }^{18}$ (shown in Figure 2). Sea spray contribution of $\mathrm{SO}_{4}^{2-}, \mathrm{K}^{+}$and $\mathrm{Ca}^{2+}$ were below $3 \%$ for all seasons. It means that sources other than marine PM were more important for these ions. These sources may be natural (for $\mathrm{K}^{+}, \mathrm{Ca}^{2+}$ and $\mathrm{Mg}^{2+}$ such as soil resuspension) or anthropic (for $\mathrm{Cl}^{-}$and $\mathrm{SO}_{4}{ }^{2-}$, for instance, vehicular and/or industrial) considering the characteristics of sampling site and São Paulo City. Anomalous (negative) values were found for $\mathrm{Cl}^{-}$(all seasons) and $\mathrm{Mg}^{2+}$ (Summer 2003-2004 and Autumn 2004) in this study. This may have happened since there have been modifications of $\mathrm{Cl}^{-}$(by volatilization losses to form gaseous $\mathrm{HCl}$ ) and $\mathrm{Mg}^{2+}$ (by enrichment due to particle soil resuspension) quantities during types 1, 3 and 4 air mass trajectories (Figure 1) together to meteorological and topological condition changes.
Trace metals in aerosols are derived from a variety of sources which include the Earth crust, oceans, volcanic activity, the biosphere and a number of anthropogenic processes (e.g., fossil fuel burning, waste incineration, the processing of ores etc.). The degree to which a trace metal in an aerosol is enriched, or depleted, relative to a specific source can be assessed to a first approximation using an enrichment factor (EF). ${ }^{19,20}$ Figure 3 presents values higher than 10 for $\mathrm{Zn}, \mathrm{Pb}$ and $\mathrm{Cu}$ which means that crustal origin is not significant for those metals. In this case, anthropic sources (biomass burning, vehicular emissions and industries) may account for them. In this way, soil resuspension seems to be important to those ones that $\mathrm{EF}$ value is smaller than $10(\mathrm{Fe}, \mathrm{Ca}, \mathrm{K}, \mathrm{Mg}$ and $\mathrm{Na})$.

Pearson correlation (95\% confidence level) was calculated and Table 5 presents the PCA (95\% confidence level) results for the studied species. Strong correlations between $\mathrm{SO}_{4}{ }^{2-}$ and $\mathrm{NH}_{4}{ }^{+}(\mathrm{r}=0.7)$ can indicate gas-to-particle

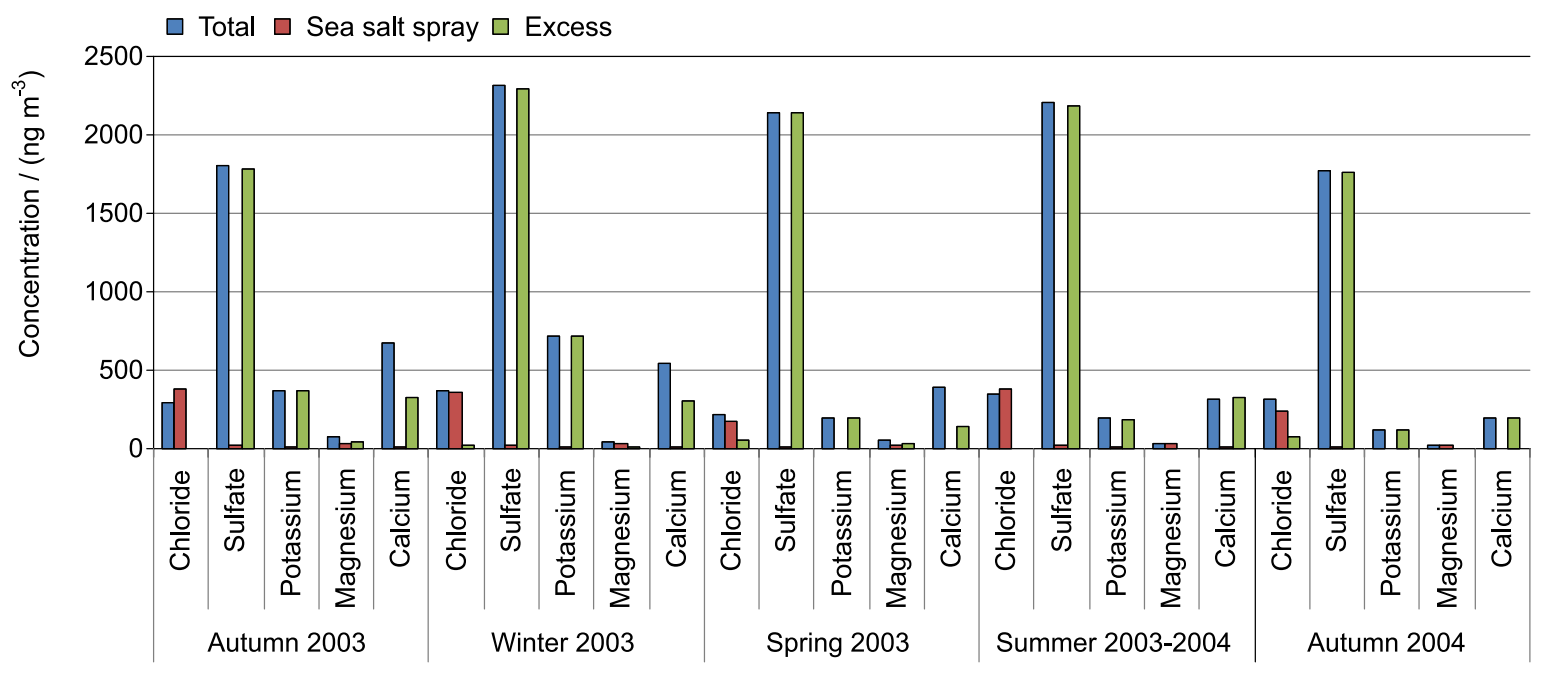

Figure 2. Sea salt spray contribution for selected ions in PM10.

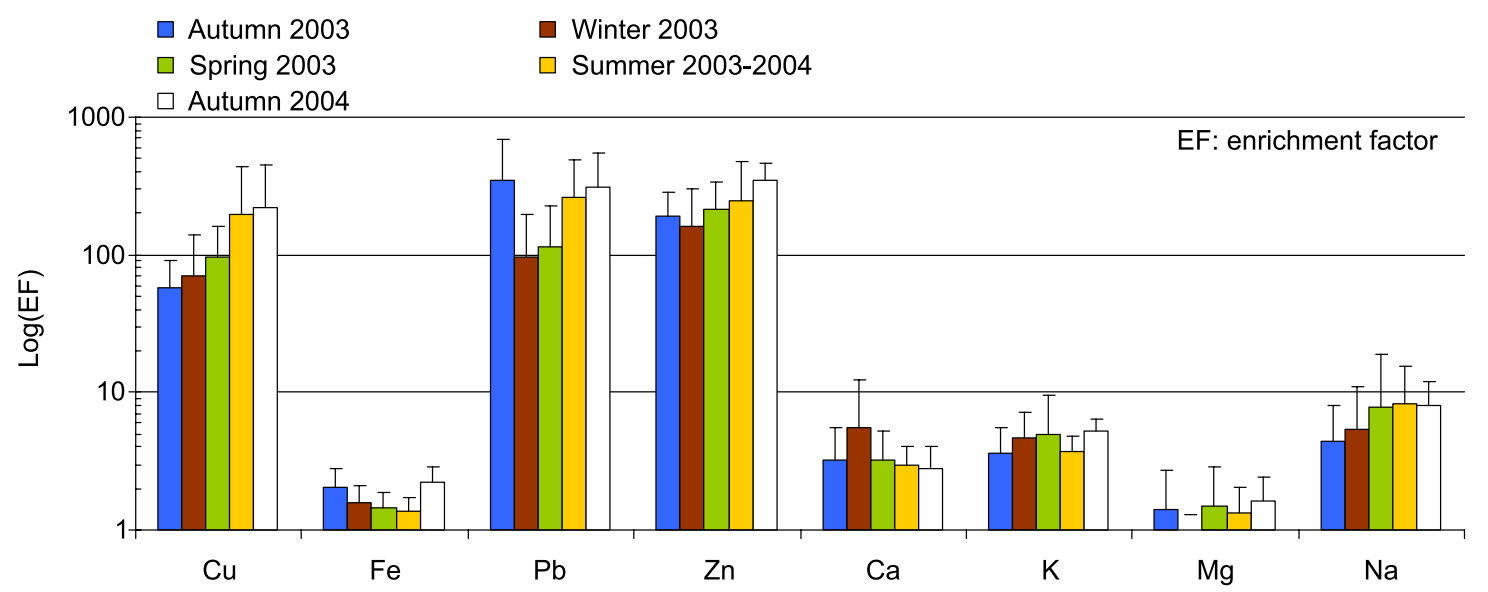

Figure 3. Logarithm of enrichment factor (EF) for elements in PM10 samples from SPA. 
contribution for those levels in PM10, which agrees with $\mathrm{NH}_{4}{ }^{+} / \mathrm{SO}_{4}{ }^{2-}$ values (Table 4 ) and discussion done there. Furthermore, moderate correlations between $\mathrm{SO}_{4}{ }^{2-}$ (which is a vehicular emission tracer) with $\mathrm{C}_{2} \mathrm{O}_{4}{ }^{2-}(\mathrm{r}=0.5)$ and $\mathrm{CH}_{3} \mathrm{COO}^{-}$and $\mathrm{C}_{2} \mathrm{O}_{4}{ }^{2-}(\mathrm{r}=0.5)$ show that vehicular source is important for sulfate and oxalate. However, weak or even negative correlations between $\mathrm{HCOO}^{-}$and $\mathrm{C}_{2} \mathrm{O}_{4}{ }^{2-}(\mathrm{r}=0.3)$, $\mathrm{CH}_{3} \mathrm{COO}^{-}$and $\mathrm{HCOO}^{-}$to $\mathrm{SO}_{4}{ }^{2-}(\mathrm{r}=-0.1$ and $\mathrm{r}=-0.01$, respectively) show other source (other than vehicular) for formate and acetate. Indeed, since there were not observed correlations among $\mathrm{CH}_{3} \mathrm{COO}^{-}$and $\mathrm{HCOO}^{-}$with sulfate but $\mathrm{CH}_{3} \mathrm{COO}^{-}$, $\mathrm{HCOO}^{-}$and $\mathrm{C}_{2} \mathrm{O}_{4}{ }^{2-}$ were relatively well correlated so this may represent another common source among them. Considering that $\mathrm{HCOO}^{-} / \mathrm{CH}_{3} \mathrm{COO}^{-}$ratios $>1$ in all seasons, it may seem that this additional source is their photochemical formation in atmosphere from precursors emitted directly such as olefins in situ oxidation. ${ }^{13,17}$ On the other hand, succinate was not well correlated with $\mathrm{HCOO}^{-}$ $(\mathrm{r}=0.1)$, with $\mathrm{C}_{2} \mathrm{O}_{4}{ }^{2-}(\mathrm{r}=-0.1)$ and with $\mathrm{SO}_{4}{ }^{2-}(\mathrm{r}=-0.2)$ but slightly correlated with $\mathrm{CH}_{3} \mathrm{COO}^{-}(\mathrm{r}=0.4)$ which means that it was not emitted neither by vehicles nor by olefins in situ oxidation. Succinate can be emitted by the metabolism of bacteria and fungi ${ }^{15-17}$ as it seems to have happened during collection period in the present study.

There were also observed weak-to-moderate correlations between $\mathrm{NH}_{4}^{+}$and $\mathrm{HCOO}^{-}(\mathrm{r}=0.2)$ as well as $\mathrm{NH}_{4}^{+}$and $\mathrm{C}_{2} \mathrm{O}_{4}{ }^{2-}(\mathrm{r}=0.5)$. Considering that $\mathrm{NH}_{4}{ }^{+}$levels were higher than $\mathrm{SO}_{4}{ }^{2-}$, there was enough $\mathrm{NH}_{4}{ }^{+}$for neutralizing other vapor acids. In this way, it is possible that the gaseous acids (formic acid and oxalic acid) have reacted with vapor $\mathrm{NH}_{3}$ generating ammonium oxalate and ammonium formate. According to Yao et al.,${ }^{17}$ the former is also a non-volatile salt that could suggest, together with ammonium sulfate, the gas-to-particle conversion contribution, while the latter is a volatile salt that could then regenerate their gaseous precursors.

Moderate-to-strong correlations $(0.5<\mathrm{r}<0.9)$ among $\mathrm{K}^{+}, \mathrm{Ca}^{2+}, \mathrm{Mg}^{2+}, \mathrm{Fe}, \mathrm{Al}, \mathrm{Ca}, \mathrm{K}$ and $\mathrm{Mg}$ show contribution of soil suspended particles by taking into consideration that $\mathrm{Fe}$ and $\mathrm{Al}$ are crustal tracers. Also, good correlations among $\mathrm{K}^{+}, \mathrm{Ca}^{2+}, \mathrm{Mg}^{2+}, \mathrm{Pb}, \mathrm{Cu}$ and $\mathrm{Zn}$ may show another source than soil suspension since $\mathrm{Pb}, \mathrm{Cu}$, and $\mathrm{Zn}$ had EF value higher than 10 . This additional source is probably anthropogenic. Considering $\mathrm{K}^{+}$as a biomass burning tracer, it is possible to consider here that it was such a probable source for them. Moreover, since Fe and Al were also well correlated with $\mathrm{Pb}, \mathrm{Cu}$ and $\mathrm{Zn}$, biomass burning was also important for $\mathrm{Fe}$ and $\mathrm{Al}$ atmospheric levels.

PCA suggests three principal components for explaining the acquired data for ions and trace metals. Significant scores (95\% confidence level) are in bold. Table 6 presents three principal components, in which PC1 explains $40.3 \%$ of total variance, $\mathrm{PC} 2$ explains $12.7 \%$ of total variance, and PC3 $11.7 \%$ of total variance. $\mathrm{PC} 1$ states for $\mathrm{NO}_{3}^{-}, \mathrm{HCOO}^{-}$,

Table 5. Pearson correlation (r) for ions and elements present in PM10 samples

\begin{tabular}{|c|c|c|c|c|c|c|c|c|c|c|c|c|c|c|c|c|c|c|c|c|c|c|}
\hline & $\mathrm{Cl}^{-}$ & $\mathrm{NO}_{3}^{-}$ & $\mathrm{PO}_{4}{ }^{3-}$ & $\mathrm{SO}_{4}^{2-}$ & $\mathrm{HCOO}^{-}$ & $-\mathrm{C}_{2} \mathrm{O}_{4}{ }^{2-}$ & Succinate & $\mathrm{CH}_{3} \mathrm{COO}^{-}$ & $\mathrm{Na}^{+}$ & $\mathrm{NH}_{4}^{+}$ & $\mathrm{K}^{+}$ & $\mathrm{Mg}^{2+}$ & $\mathrm{Ca}^{2+}$ & $\mathrm{Cu}$ & $\mathrm{Fe}$ & $\mathrm{Pb}$ & $\mathrm{Zn}$ & $\mathrm{Al}$ & $\mathrm{Ca}$ & $\mathrm{K}$ & $\mathrm{Mg}$ & $\mathrm{Na}$ \\
\hline $\mathrm{Cl}^{-}$ & 1 & & & & & & & & & & & & & & & & & & & & & \\
\hline $\mathrm{NO}_{3}^{-}$ & 0.10 & 1 & & & & & & & & & & & & & & & & & & & & \\
\hline $\mathrm{PO}_{4}^{3-}$ & -0.20 & 0.56 & 1 & & & & & & & & & & & & & & & & & & & \\
\hline $\mathrm{SO}_{4}^{2-}$ & 0.27 & 0.35 & 0.15 & 1 & & & & & & & & & & & & & & & & & & \\
\hline $\mathrm{HCOO}^{-}$ & -0.02 & 0.38 & 0.00 & -0.01 & 1 & & & & & & & & & & & & & & & & & \\
\hline $\mathrm{C}_{2} \mathrm{O}_{4}^{2-}$ & 0.04 & 0.38 & 0.02 & 0.57 & 0.35 & 1 & & & & & & & & & & & & & & & & \\
\hline Succinate & -0.10 & -0.09 & 0.07 & -0.23 & 0.09 & -0.08 & 1 & & & & & & & & & & & & & & & \\
\hline $\mathrm{CH}_{3} \mathrm{COO}^{-}$ & -0.20 & 0.30 & -0.06 & -0.06 & 0.58 & 0.54 & 0.39 & 1 & & & & & & & & & & & & & & \\
\hline $\mathrm{Na}^{+}$ & 0.55 & 0.14 & 0.19 & 0.14 & -0.22 & -0.05 & -0.13 & -0.26 & 1 & & & & & & & & & & & & & \\
\hline $\mathrm{NH}_{4}^{+}$ & 0.18 & 0.24 & -0.20 & 0.73 & 0.22 & 0.53 & -0.23 & 0.03 & 0.16 & 1 & & & & & & & & & & & & \\
\hline $\mathrm{K}^{+}$ & 0.10 & 0.31 & 0.06 & 0.03 & 0.35 & 0.38 & -0.03 & 0.26 & 0.06 & 0.10 & 1 & & & & & & & & & & & \\
\hline $\mathrm{Mg}^{2+}$ & 0.15 & 0.46 & 0.55 & 0.29 & 0.06 & 0.48 & -0.19 & 0.03 & 0.39 & 0.05 & 0.30 & 1 & & & & & & & & & & \\
\hline $\mathrm{Ca}^{2+}$ & 0.13 & 0.43 & 0.39 & 0.26 & 0.24 & 0.64 & 0.02 & 0.20 & 0.18 & 0.14 & 0.64 & 0.74 & 1 & & & & & & & & & \\
\hline $\mathrm{Cu}$ & 0.29 & 0.13 & 0.20 & 0.23 & 0.04 & 0.43 & 0.21 & 0.20 & 0.33 & 0.10 & 0.08 & 0.45 & 0.37 & 1 & & & & & & & & \\
\hline $\mathrm{Fe}$ & 0.16 & 0.44 & 0.31 & 0.22 & 0.25 & 0.51 & 0.03 & 0.20 & 0.10 & 0.04 & 0.70 & 0.57 & 0.91 & 0.29 & 1 & & & & & & & \\
\hline $\mathrm{Pb}$ & 0.00 & 0.39 & 0.63 & 0.07 & 0.08 & 0.22 & 0.50 & 0.14 & 0.22 & -0.22 & 0.25 & 0.49 & 0.70 & 0.37 & 0.63 & 1 & & & & & & \\
\hline $\mathrm{Zn}$ & 0.32 & 0.41 & 0.40 & 0.44 & -0.16 & 0.37 & -0.13 & -0.21 & 0.46 & 0.17 & 0.27 & 0.60 & 0.74 & 0.42 & 0.70 & 0.65 & 1 & & & & & \\
\hline $\mathrm{Al}$ & 0.15 & 0.33 & 0.17 & 0.16 & 0.29 & 0.54 & 0.05 & 0.25 & 0.01 & 0.03 & 0.80 & 0.51 & 0.87 & 0.28 & 0.96 & 0.51 & 0.56 & 1 & & & & \\
\hline $\mathrm{Ca}$ & 0.18 & 0.49 & 0.28 & 0.16 & 0.58 & 0.47 & -0.04 & 0.20 & 0.15 & 0.16 & 0.74 & 0.58 & 0.84 & 0.21 & 0.86 & 0.51 & 0.52 & 0.86 & 1 & & & \\
\hline $\mathrm{K}$ & 0.30 & 0.38 & 0.09 & 0.16 & 0.33 & 0.45 & 0.06 & 0.22 & 0.04 & 0.10 & 0.88 & 0.41 & 0.79 & 0.19 & 0.87 & 0.41 & 0.47 & 0.91 & 0.85 & 1 & & \\
\hline $\mathrm{Mg}$ & 0.30 & 0.56 & 0.14 & 0.17 & 0.27 & 0.44 & -0.13 & 0.24 & 0.14 & 0.09 & 0.67 & 0.53 & 0.69 & 0.12 & 0.78 & 0.32 & 0.50 & 0.77 & 0.76 & 0.80 & 1 & \\
\hline $\mathrm{Na}$ & 0.73 & 0.07 & -0.01 & 0.16 & -0.17 & -0.06 & v0.19 & -0.24 & 0.90 & 0.11 & 0.10 & 0.28 & 0.08 & 0.20 & 0.06 & 0.04 & 0.37 & 0.02 & 0.13 & 0.10 & 0.21 & 1 \\
\hline
\end{tabular}

Significant scores (95\% confidence level) are in bold. 
$\mathrm{C}_{2} \mathrm{O}_{4}{ }^{2-}, \mathrm{K}^{+}, \mathrm{Mg}^{2+}, \mathrm{Ca}^{2+}, \mathrm{Fe}, \mathrm{Pb}, \mathrm{Zn}, \mathrm{Al}, \mathrm{Ca}, \mathrm{K}$ and $\mathrm{Mg}, \mathrm{PC} 2$ states for $\mathrm{SO}_{4}{ }^{2-}$ and $\mathrm{NH}_{4}{ }^{+}$, and $\mathrm{PC} 3$ represents $\mathrm{Na}^{+}, \mathrm{Cl}^{-}$and $\mathrm{Na}$. Our group tentatively proposes that $\mathrm{PC} 1$ represents a mixed contribution of biomass burning (since $\mathrm{K}^{+}$is used as this source tracer) and/or automobile fuel burning, PC2 represents gas-to-particle conversion, and PC 3 represents the sea spray contribution. These assumptions agree with the contribution of the four types of air mass trajectories discussed earlier. During biomass burning, it is difficult to distinguish releases due to burning by itself from soil suspension. Indeed, when biomass is being burnt, soil particles are suspended into fire and often biomass burning is associated with soil suspension. This may explain high scores for $\mathrm{Al}, \mathrm{Fe}, \mathrm{Mg}$ and $\mathrm{Ca}$ (soil suspension tracers) in $\mathrm{PC} 1$, as also observed by the EF value of them.

Dry atmospheric deposition fluxes $\left(\mathrm{F}_{\mathrm{d}}\right)$ were calculated by multiplying the geometric mean particulate concentration in air of the element of interest by the elemental dry settling velocity. ${ }^{21}$ Table 7 presents seasonal estimates of dry deposition fluxes for selected ions and trace metals from PM10 samples. Since values of $F_{d}$ are higher for both Autumn 2003 and Winter 2003 (characterized as drier seasons) than other seasons, it was possible to say that dry deposition was the predominant removal mechanism in these periods while probably wet deposition had a higher influence in Spring 2003, Summer 2003-2004 and exceptionally in Autumn 2004.

In a previous study done in July 2003 in São Paulo State, at SPA, Araraquara (ARQ) and Piracicaba (PRB) sites, sugar cane burning and industrial activities were the major emissions sources. ${ }^{14}$ Burning of solid waste and biomass on small properties and at landfills was responsible for the high
Table 6. Principal component analyses (PCA) for major ions and elements found in PM10 samples

\begin{tabular}{|c|c|c|c|}
\hline \multirow{2}{*}{ Species } & $\mathrm{PC} 1$ & $\mathrm{PC} 2$ & PC3 \\
\hline & $40.3 \%$ & $12.7 \%$ & $11.7 \%$ \\
\hline $\mathrm{Cl}^{-}$ & -0.166 & 0.359 & -0.520 \\
\hline $\mathrm{NO}_{3}^{-}$ & -0.591 & 0.045 & 0.183 \\
\hline $\mathrm{PO}_{4}^{3-}$ & -0.487 & 0.136 & -0.043 \\
\hline $\mathrm{SO}_{4}^{2-}$ & -0.340 & 0.797 & 0.401 \\
\hline $\mathrm{HCOO}^{-}$ & -0.592 & -0.350 & 0.277 \\
\hline $\mathrm{C}_{2} \mathrm{O}_{4}{ }^{2-}$ & -0.678 & 0.290 & 0.488 \\
\hline succinate & -0.095 & -0.365 & 0.096 \\
\hline $\mathrm{CH}_{3} \mathrm{COO}^{-}$ & -0.351 & -0.312 & 0.488 \\
\hline $\mathrm{Na}^{+}$ & -0.131 & 0.395 & -0.763 \\
\hline $\mathrm{NH}_{4}^{+}$ & -0.184 & 0.591 & 0.530 \\
\hline $\mathrm{K}^{+}$ & -0.709 & -0.336 & -0.059 \\
\hline $\mathrm{Mg}^{2+}$ & -0.694 & 0.244 & -0.240 \\
\hline $\mathrm{Ca}^{2+}$ & -0.945 & -0.037 & -0.067 \\
\hline $\mathrm{Cu}$ & -0.375 & 0.286 & -0.107 \\
\hline $\mathrm{Fe}$ & -0.932 & -0.152 & -0.092 \\
\hline $\mathrm{Pb}$ & -0.706 & -0.037 & -0.010 \\
\hline $\mathrm{Zn}$ & -0.714 & 0.266 & -0.166 \\
\hline $\mathrm{Al}$ & -0.899 & -0.242 & -0.049 \\
\hline $\mathrm{Ca}$ & -0.931 & -0.171 & -0.112 \\
\hline K & -0.854 & -0.231 & -0.084 \\
\hline $\mathrm{Mg}$ & -0.800 & -0.173 & -0.117 \\
\hline $\mathrm{Na}$ & -0.098 & 0.421 & -0.757 \\
\hline
\end{tabular}

Significant scores (95\% confidence level) are in bold.

$\mathrm{Cl}^{-}$ion concentrations at SPA site. The abundance of $\mathrm{NO}_{3}^{-}$, $\mathrm{SO}_{4}{ }^{2-}$ and $\mathrm{K}^{+}$at ARQ site suggested that the atmosphere was influenced by vehicular and biomass burning emissions. The presence of $\mathrm{NO}_{3}^{-}, \mathrm{SO}_{4}{ }^{2-}, \mathrm{Fe}, \mathrm{Al}, \mathrm{Ca}$ and $\mathrm{K}$ at the $\mathrm{PRB}$ site suggested that soil resuspension and sugarcane burning

Table 7. Seasonal estimates of aerosol dry deposition flux $\left(F_{d}\right)$ for selected ions and elements in the PM10 samples

\begin{tabular}{|c|c|c|c|c|c|c|c|c|c|c|c|c|c|c|c|c|c|}
\hline & $\mathrm{Cl}^{-\mathrm{a}}$ & $\mathrm{NO}_{3}^{-\mathrm{a}}$ & $\mathrm{SO}_{4}^{2-\mathrm{a}}$ & $\mathrm{HCOO}^{-\mathrm{b}}$ & $\mathrm{CH}_{3} \mathrm{COO}^{-\mathrm{b}}$ & $\mathrm{Na}^{+\mathrm{a}}$ & $\mathrm{NH}_{4}{ }^{+a}$ & $\mathrm{~K}^{+\mathrm{a}}$ & $\mathrm{Mg}^{2+\mathrm{c}}$ & $\mathrm{Ca}^{2+\mathrm{c}}$ & $\mathrm{Cu}^{\mathrm{d}}$ & $\mathrm{Fe}^{\mathrm{d}}$ & $\mathrm{Pb}^{\mathrm{d}}$ & $\mathrm{Zn}^{\mathrm{d}}$ & $\mathrm{Al}^{\mathrm{e}}$ & $\mathrm{Ca}^{\mathrm{f}}$ & $\mathrm{Mg}^{\mathrm{d}}$ \\
\hline Dry settling veloc. $\left(\mathrm{V}_{\mathrm{d}}\right) /\left(\mathrm{cm} \mathrm{s}^{-1}\right)$ & 4.1 & 0.27 & 0.52 & 0.5 & 1.0 & 3.49 & 0.13 & 3.9 & 1.5 & 2.1 & 0.4 & 1 & 1.5 & 0.8 & 0.15 & 1.07 & 0.3 \\
\hline \multicolumn{18}{|l|}{ Autumn 2003} \\
\hline Geometric mean / $\left(\mathrm{ng} \mathrm{m}^{-3}\right)$ & 213.8 & 1193 & 1413 & 49.80 & 9.200 & 253.6 & 579.0 & 333.0 & 69.50 & 565.1 & 26.50 & 928.2 & 32.10 & 90.40 & 636.9 & 964.0 & 223.9 \\
\hline $\mathrm{F}_{\mathrm{d}} /\left(\mu \mathrm{g} \mathrm{m}^{-2}\right.$ day $\left.^{-1}\right)$ & 757.4 & 278.2 & 635.0 & 21.53 & 7.97 & 764.7 & 65.03 & 1122 & 90.03 & 1025 & 9.160 & 802.0 & 41.61 & 62.45 & 82.54 & 891.2 & 58.03 \\
\hline \multicolumn{18}{|l|}{ Winter 2003} \\
\hline Geometric mean / $\left(\mathrm{ng} \mathrm{m}^{-3}\right)$ & 326.0 & 1206 & 2007 & 160.7 & 9.400 & 222.5 & 1029 & 522.8 & 40.90 & 480.2 & 24.20 & 678.2 & 23.30 & 62.90 & 591.3 & 1091 & 184.6 \\
\hline $\mathrm{F}_{\mathrm{d}} /\left(\mu \mathrm{g} \mathrm{m}^{-2}\right.$ day $\left.^{-1}\right)$ & 1155 & 281.3 & 901.9 & 69.41 & 8.110 & 670.9 & 115.5 & 1762 & 53.06 & 871.2 & 8.350 & 586.0 & 30.18 & 43.49 & 76.64 & 1008 & 47.84 \\
\hline \multicolumn{18}{|l|}{ Spring 2003} \\
\hline Geometric mean / $\left(\mathrm{ng} \mathrm{m}^{-3}\right)$ & 123.5 & 502.3 & 1738 & 29.20 & 7.000 & 112.5 & 599.8 & 193.8 & 41.70 & 359.5 & 17.10 & 304.9 & 15.60 & 43.00 & 289.5 & 461.4 & 115.4 \\
\hline $\mathrm{F}_{\mathrm{d}} /\left(\mu \mathrm{g} \mathrm{m}^{-2}\right.$ day $\left.^{-1}\right)$ & 437.4 & 117.2 & 780.9 & 12.62 & 6.090 & 339.2 & 67.37 & 652.9 & 54.02 & 652.2 & 5.920 & 263.4 & 20.27 & 29.74 & 37.52 & 426.6 & 29.92 \\
\hline \multicolumn{18}{|l|}{ Summer 2003-2004 } \\
\hline Geometric mean / $\left(\mathrm{ng} \mathrm{m}^{-3}\right)$ & 252.4 & 380.1 & 1909 & 25.20 & 3.300 & 214.8 & 619.2 & 187.9 & 17.80 & 297.6 & 31.70 & 294.0 & 21.70 & 71.20 & 301.8 & 465.6 & 114.7 \\
\hline $\mathrm{F}_{\mathrm{d}} /\left(\mu \mathrm{g} \mathrm{m}^{-2}\right.$ day $\left.^{-1}\right)$ & 894.2 & 88.68 & 857.7 & 10.88 & 2.870 & 647.7 & 69.55 & 633.2 & 23.05 & 540.0 & 10.94 & 254.1 & 28.15 & 49.23 & 39.11 & 430.4 & 29.73 \\
\hline \multicolumn{18}{|l|}{ Autumn 2004} \\
\hline Geometric mean / $\left(\mathrm{ng} \mathrm{m}^{-3}\right)$ & 280.6 & 424.2 & 1488 & 24.50 & 8.400 & 112.2 & 347.3 & 103.6 & 16.10 & 157.4 & 26.70 & 365.3 & 10.50 & 63.60 & 224.0 & 320.7 & 111.2 \\
\hline$F_{d} /\left(\mu \mathrm{g} \mathrm{m}^{-2}\right.$ day $\left.^{-1}\right)$ & 994.2 & 98.95 & 668.7 & 10.59 & 7.290 & 338.4 & 39.01 & 349.1 & 20.81 & 285.7 & 9.210 & 315.6 & 13.63 & 43.94 & 29.03 & 296.5 & 28.82 \\
\hline
\end{tabular}

${ }^{\mathrm{a}}$ Reference 22; ${ }^{\mathrm{b}}$ reference 23; ${ }^{\mathrm{c}}$ reference 24; ${ }^{\mathrm{d}}$ reference 25; ${ }^{\mathrm{e}}$ reference 26; ${ }^{\mathrm{f}}$ reference 27. 
have strong influences. Despite the PM10 and species levels found in the intensive campaign were higher than those found in the different seasons; the main emissions sources were similar in both campaigns.

\section{Conclusions}

The present study showed that for $\mathrm{NH}_{4}{ }^{+}$and $\mathrm{SO}_{4}{ }^{2-}$, secondary process (gas-to-particle conversion) via reaction between their vapor precursors was one relevant ion source in PM10. Sea salt spray was a minor source for some ions $\left(\mathrm{Cl}^{-}, \mathrm{SO}_{4}{ }^{2-}, \mathrm{K}^{+}, \mathrm{Ca}^{2+}\right.$ and $\left.\mathrm{Mg}^{2+}\right)$. Instead, other sources were more important such as natural (for $\mathrm{Al}, \mathrm{Fe}, \mathrm{Ca}$ and $\mathrm{Mg}$ ) or anthropogenic $\left(\mathrm{Cl}^{-}\right.$and $\mathrm{SO}_{4}{ }^{2-}$, vehicular). Some sources were predominant for some species: $(i)$ fuel burning and/or biomass burning $\left(\mathrm{NO}_{3}^{-}, \mathrm{HCOO}^{-}, \mathrm{C}_{2} \mathrm{O}_{4}{ }^{2-}, \mathrm{K}^{+}, \mathrm{Mg}^{2+}, \mathrm{Ca}^{2+}, \mathrm{Fe}\right.$, $\mathrm{Pb}, \mathrm{Zn}, \mathrm{Al}, \mathrm{Ca}, \mathrm{K}$ and $\mathrm{Mg}$ ), (ii) gas-to-particle conversion $\left(\mathrm{SO}_{4}{ }^{2-}\right.$ and $\left.\mathrm{NH}_{4}{ }^{+}\right)$and (iii) sea salt spray $\left(\mathrm{Cl}^{-}, \mathrm{Na}^{+}\right.$and $\left.\mathrm{Na}\right)$.

\section{Acknowledgements}

Authors wish to thank the following research support agencies: Fundação de Amparo à Pesquisa do Estado de São Paulo (FAPESP Project No. 2001/01763-0) and Conselho Nacional de Conselho Científico e Tecnológico (CNPq). P. C. Vasconcellos and G. O. Da Rocha acknowledge CNPq for their research fellowships.

\section{References}

1. Kumagai, K.; Iijima, A.; Tago, H.; Tomioga, A.; Kozawa, K.; Sakamoto K.; Atmos. Environ. 2009, 43, 3345.

2. Singh, R.; Bhupendra, S.; Sharma, S. B.; Chalka, S. N.; Environ. Monit. Assess. 2010, 168, 195.

3. Srimuruganandam, B.; Nagendra, S. M. S.; Sci. Total Environ. 2012, 433, 8 .

4. Harrison, R. M.; Giorio, C.; Beddows, D. C. S.; Dall'Osto; Sci. Total Environ. 2010, 409, 289.

5. Chiarelli,P. S.; Pereira, L.A.A.; Saldiva,P.H. N.; Ferreira Filho, C.; Garcia, M. L. B.; Braga, A. L. F.; Martins, L. C.; Environ. Res. 2011, 111, 650 .

6. Novaes, P.; Saldiva, P. H. N.; Matsuda, M.; Macchione, M.; Rangel, M. P.; Kara-José, N.; Berra, A.; Environ. Res. 2010, 110,372 .

7. Olmo, N. R. S.; Saldiva, P. H. N.; Braga, A. L. F.; Lin, C. A.; Santos, U. P.; Pereira, L. A. A.; Clinics 2011, 66, 681.

8. Davel, A. P.; Lemos, M.; Pastro, L. M.; Pedro, S. C.; André, P. A., Hebeda, C.; Farsky, S. H. Saldiva, P. H.; Rossoni, L. V.; Toxicology 2012, 295, 39.
9. http://www.euro.who.int/_data/assets/pdf_file/0005/78638/ E90038.pdf, accessed in October 2012.

10. López, J. M.; Callén, M. S.; Murillo, R.; García, T.; Navarro, M. V.; de la Cruz, M. T.; Mastral, A. M.; Environ. Res. 2005, 99, 58.

11. Vasconcellos, P. C.; Balasubramanian, R.; Bruns, R. E.; Sanchez-Ccoyllo, O.; Andrade, M. F.; Flues M.; Water, Air, Soil Pollut. 2007, 186, 63.

12. Allen, A. G.; Cardoso, A. A.; da Rocha, G. O.; Atmos. Environ. 2004, 38, 5025.

13. da Rocha, G. O.; Allen, A. G.; Cardoso, A. A.; Environ. Sci. Technol. 2005, 39, 5293.

14. Vasconcellos, P. C.; Souza, D. Z.; Magalhães, D.; da Rocha, G. O.; Water, Air, Soil Pollut. 2011, 222, 325.

15. Kawamura, K.; Ikushima, K.; Environ. Sci. Technol. 1993, 27, 2227.

16. Kawamura, K.; Kaplan, I. R.; Environ. Sci. Technol. 1985, 19, 1082.

17. Yao, X.; Fang, M.; Chan, C. K.; Ho, K. F.; Lee, S. C.; Atmos. Environ. 2004, 38, 963.

18. Souza, P. A.; Mello, W. Z.; Mariani, R. L.; Sella, R. M.; Quim. Nova 2010, 33, 1247.

19. Sardans, J.; Peñuelas, J.; Chemosphere 2005, 60, 1293.

20. Pereira, P. A. P.; Lopes, W. A.; Carvalho, L. S.; da Rocha, G. O.; Bahia, N. C.; Loyola, J.; Quitério, S. L.; Escaladera, V.; Arbilla, G.; de Andrade, J. B.; Atmos. Environ. 2007, 41, 7837.

21. Da Rocha, G. O.; Lopes, W.A.; Pereira, P.A.P.; Vasconcellos, P.C.; Santos, F. O.; Carvalho, L. S.; Conceição, L. S.; de Andrade, J. B.; J. Braz. Chem. Soc. 2009, $20,680$.

22. Chu, C. C.; Fang, G. C.; Chen, J. C.; Yang, I.; Environ. Monit. Assess. 2008, 146, 441.

23. Khare, P.; Kumar, N.; Satsangi, G. S.; Kumari, K. M.; Srivastava, S. S.; Chemosphere 1998, 36, 2993.

24. Cadle, S. H.; Dasch, J. M.; Mulawa, P. A.; Atmos. Environ. 1985, 19, 1819.

25. Fang, G. C.; Wu, Y. S.; Chang, S. Y.; Lin, J. B.; Lin, J. G.; Chemosphere 2007, 67, 966.

26. Quinn, T. L.; Ondov, J. M.; Atmos. Environ. 1998, 32, 3467.

27. Odabasi, M.; Muezzinoglu, A.; Bozlaker, A.; Atmos. Environ. 2002, 36, 5841 .

Submitted: April 8, 2012

Published online: October 26, 2012

FAPESP has sponsored the publication of this article. 